\title{
Influence of NIR Laser and Alternating Magnetic Field on Core-Shell Nanoparticles for Cell Lines Treatment
}

rusul mohammed ( $\square$ mh_rusul@yahoo.com )

University of Baghdad https://orcid.org/0000-0002-0129-953X

raad Al-Haddad

University of Baghdad

\section{Research Article}

Keywords: Fe30-4Au @Si02, NIR laser , alternating magnetic field, MTT assay, optical properties , magnetic properties

Posted Date: August 24th, 2021

DOI: https://doi.org/10.21203/rs.3.rs-804794/v1

License: (c) (i) This work is licensed under a Creative Commons Attribution 4.0 International License.

Read Full License 


\title{
Influence of NIR Laser and alternating magnetic field on $\mathrm{Fe}_{3} \mathrm{O}_{4}-\mathrm{Au} @ \mathrm{SiO}_{2}$ Core-Shell Nanoparticles for cell lines treatment
}

\author{
*Rusul Mohammed Abdallah, Raad M. S. Al-Haddad \\ Department of Physics, College of Sciences, University of Baghdad, Baghdad, Iraq. \\ *mh_rusul@yahoo.com $\quad \underline{\text { raad.m@sc.uobaghdad.edu.iq }}$
}

\begin{abstract}
Core-shell nanoparticles (CSNPs) have attracted attention in biomedical applications as they have highly useful materials with modified characteristics, such as high stability, dispersibility, higher permeability to certain target cells and reduction in consumption of precious materials. Synthesis of core-multishell nanoparticles with suitable sizes, structural characteristics and absorption using simple methods continues to be a challenge. In this study, $\mathrm{Fe}_{3} \mathrm{O}_{4}-\mathrm{Au} @ \mathrm{SiO}_{2} \mathrm{CSNPs}$ were synthesized in three stages to control their size and the potential for tuning their properties. FESEM images confirmed that $\mathrm{Fe}_{3} \mathrm{O}_{4}-\mathrm{Au} @ \mathrm{SiO}_{2}$ CSNPs has a small particle size of about $22.5 \mathrm{~nm}$; average crystalline size in XRD was $22.8 \mathrm{~nm}$; stability was about $-49.1 \mathrm{mV}$; and synthesis with magnetic and optical properties improved their biocompatibility. Treatment of CAL-51 and HBL-100 cell lines by $\mathrm{Fe}_{3} \mathrm{O}_{4}$-Au @SiO ${ }_{2}$ CSNPs under NIR laser and alternating magnetic field (AMF) generated enough heat to increase cell death.
\end{abstract}

Keywords: $\mathrm{Fe}_{3} \mathrm{O}_{4}-\mathrm{Au} @ \mathrm{SiO}_{2} \mathrm{CSNP}$, NIR laser, alternating magnetic field, MTT assay, optical properties , magnetic properties.

\section{Introduction}

Magnetic nanostructures are being used in biomedical applications because of their high magnetic susceptibilities and very low toxicity [1-4]. $\mathrm{Fe}_{3} \mathrm{O}_{4}$ NPs has been used for cancer diagnostics and treatment due to its thermal characteristics (induction of heat for destroying cancer cells), as well as certain properties of magnetic particles such as size, shape and strength of their field, and saturation magnetization [5]. Localized surface plasmon resonances (LSPR) in nanoparticles can produce strong optical resonances at visible and near-infrared wavelengths [6]. $\mathrm{Fe}_{3} \mathrm{O}_{4} \mathrm{NPs}$ do have plasmonic properties, exhibiting LSPR due to their large electron density [7]. However, they are not as strong as gold nanoparticles. This is because of differences between the electronic structures of the two materials [8]. Gold nanoparticles (AuNPs) are used in medicine because of their unique optical properties, known as localized surface plasmon resonance (LSPR), and their high level of stability, as well as their potential to combine with biomolecules [9]. In aqueous 
solutions, magnetites become corroded, agglomerated and unstable. Silica shells on the surface of the core make it dispersible in liquids, which improves biocompatibility by allowing it to be coupled with various medicines and biomolecules [10-12]. The combination of two functionalities, $\mathrm{Fe}_{3} \mathrm{O}_{4}$ NPs magnetization and $\mathrm{Au}$ nanomaterial nearinfrared (NIR) absorption, would allow for effective imaging and therapy for a variety of critical diseases. However, combining different surfaces is difficult, leading to low dispersion, failure to synthesize MGNPs with NIR responses and, as a result, potentially undesirable physicochemical characteristics [13]. Synthesis of core-multishell with suitable sizes, structural characteristics and absorption using simple methods continues to be a challenge [14]. Yang et al. [15] prepared $\mathrm{Fe}_{3} \mathrm{O}_{4}-\mathrm{Au} @ \mathrm{SiO}_{2} \mathrm{CSNPs}$ with spherical shape but at micro scale and over a long time, exceeding $16 \mathrm{~h}$. Amatatongchai et al. [16] synthesized $\mathrm{Fe}_{3} \mathrm{O}_{4}$ - $\mathrm{Au} @ \mathrm{SiO}_{2} \mathrm{CSNPs}$ to provide excellent features for electrochemical sensors but by complex and expensive methods, with particle size $<50 \mathrm{~nm}$ and with nonuniform shapes. To avoid these problems, we synthesized $\mathrm{Fe}_{3} \mathrm{O}_{4}-\mathrm{Au} @ \mathrm{SiO}_{2} \mathrm{CSNPs}_{\text {in }}$ three stages, in order to control their chemical composition, relative size and the potential for tuning their properties safely, at low cost, in a short synthesis time of about $4 \mathrm{~h}$, with sherical shape and on a scale of not more than $25 \mathrm{~nm}$. This was done by first synthesizing

a core $\mathrm{Fe}_{3} \mathrm{O}_{4}$ NPs using a green method, then synthesizing highly efficient $\mathrm{Fe}_{3} \mathrm{O}_{4} @ \mathrm{Au}$ CSNPs by an ecologically friendly, sonochemical method that rapidly produces smaller particles and satisfactory properties [17], and finally coating with scilica to avoid aggrelation and effectively enhance biocompatibility. MTT assay was also used to evaluate the effect of $\mathrm{Fe}_{3} \mathrm{O}_{4}-\mathrm{Au} @ \mathrm{SiO}_{2}$ on CAL-51 and HBL-100 cell lines. The result showed that cytotoxic effect was increased in the presence of NIR laser and alternating magnetic field (AMF), because a good LSPR (Au NPs) absorbed NIR laser and converted to heat, and the presence of $\mathrm{Fe}_{3} \mathrm{O}_{4}$ NPs under alternating magnetic field also generated enough heat to inactivate infected cell lines.

\section{Experimental Details}

\subsection{Materials}

Ferric chloride hexahydrate $\left(\mathrm{FeCl}_{3} .6 \mathrm{H}_{2} \mathrm{O}\right)$ and Ferrous chloride tetrahydrate $\left(\mathrm{FeCl}_{2} .4 \mathrm{H}_{2} \mathrm{O}\right)$ were procured from Panreac AppliChem in Barcelona (Spain). Hydrogen tetrachloroauric acid $\left(\mathrm{HAuCl}_{4} \cdot 4 \mathrm{H}_{2} \mathrm{O}\right)$ was procured from Riedel-Dehaenag/Seelz-Hannover (Germany). Etraethyl orthosilicate (TEOS), sodium hydroxide $(\mathrm{NaOH})$, trisodium citrate dihydrate $\left(\mathrm{Na}_{3} \mathrm{C}_{6} \mathrm{H}_{5} \mathrm{O}_{7}\right)$, cetyltrimethylammonium bromide $(\mathrm{CTAB})$ and ammonia aqueous solution (25 wt\%) were purchaed from Aladdin Chemical Co. LTD (China). All solutions were synthesized with deionized water. CAL-51 (human breast cancer cell line) and HBL-100 (a breast nontumorogenic cell line) were provided by the Iraqi Center for Cancer and Medical Genetic Research (ICCMGR). 


\subsection{Synthesis of $\mathrm{Fe}_{3} \mathrm{O}_{4}-\mathrm{Au} @ \mathrm{SiO}_{2} \mathrm{CSNPs}$}

Three stages make up the process of synthesis: part A, synthesis of $\mathrm{Fe}_{3} \mathrm{O}_{4} \mathrm{NPs}$ by green method; part $\mathrm{B}$, synthesis of $\mathrm{Fe}_{3} \mathrm{O}_{4} @ \mathrm{Au}$ by sonochemical method; part $\mathrm{C}$, synthesis of $\mathrm{Fe}_{3} \mathrm{O}_{4}-\mathrm{Au} @ \mathrm{SiO}_{2} \mathrm{CSNPs}$.

A. $\mathrm{Fe}_{3} \mathrm{O}_{4}$-NPs were synthesized by a green method using carob leaf extract. $\mathrm{FeCl}_{2} \cdot 4 \mathrm{H}_{2} \mathrm{O}$ and $\mathrm{FeCl} 3.6 \mathrm{H}_{2} \mathrm{O}\left(1 / 2\right.$ molarratio) were dissolved in deionized water and heated at $80^{\circ} \mathrm{C}$. Into this solution, a carob leaf extract solution was added and the yellow colour of the mix changed to brown. After that, $\mathrm{NaOH}$ was added to the mixture, with constant stirring to adjust the $\mathrm{pH}$ to 8 , and the colour of the mix changed to dark brown. This was followed by constant stirring for $20 \mathrm{~min}$ until the reaction was complete and cooled to room temperature. Magnetite nanoparticles were washed several times with deionized water, after which they were centrifuged and the collected precipitates were oven-dried at $70^{\circ} \mathrm{C}$.

B. $\mathrm{Fe}_{3} \mathrm{O}_{4} @ \mathrm{Au}$ CSNPs were prepared using sonochemical method, with ultrasonic frequency at $45 \mathrm{kHz}, 120 \mathrm{~W} .0 .01 \mathrm{~g} \mathrm{Fe}_{3} \mathrm{O}_{4} \mathrm{NPs}$ were dispersed in $15 \mathrm{~mL}$ of deionized water and ulrasonicated for $60 \mathrm{~s}$. Then $25 \mathrm{~mL}(0.001 \mathrm{M})$ of $\mathrm{HAuCl}_{4}$ solution was added, The solution was ulrasonicated for $2 \mathrm{~min}$, after which $5 \mathrm{~mL}$ sodium citrate $(0.03 \mathrm{M})$ was added. The mixture was again ultrasonicated for $20 \mathrm{~min}$ and heated to $45^{\circ} \mathrm{C}$. The colour changed immediately to brown and gradually to dark burgundy. Next, a magnet was used to collect CSNPs, which were then washed several times with deionized water. The collected precipitates were oven-dried at $70^{\circ} \mathrm{C}$.

C. $\mathrm{Fe}_{3} \mathrm{O}_{4}-\mathrm{Au} @ \mathrm{SiO}_{2} \mathrm{CSNPs}$ were prepared. $0.01 \mathrm{~g}$ of $\mathrm{Fe}_{3} \mathrm{O}_{4}$-Au was dispersed in $25 \mathrm{~mL}$ of deionised water, $30 \mathrm{~mL}$ of ethanol, $5 \mathrm{mg}$ of CTAB (as templates) and $0.5 \mathrm{~mL}$ of ammonia aqueous solution $(25 \mathrm{Wt} \%$ ) in a stirrer for $30 \mathrm{~min}$. After that, $0.3 \mathrm{~mL}$ TEOS was added drop-wise, with continuous stirring for $3 \mathrm{~h}$. The colour of the solution changed immediately from burgundy and slowly to purple. The product was then collected, washed several times with ethanol and deionized water and dried in an oven at $70^{\circ} \mathrm{C}$. The stock solution of $\mathrm{Fe}_{3} \mathrm{O}_{4}-\mathrm{Au} @ \mathrm{SiO}_{2} \mathrm{CSNP}$ is shown in Fig.1.
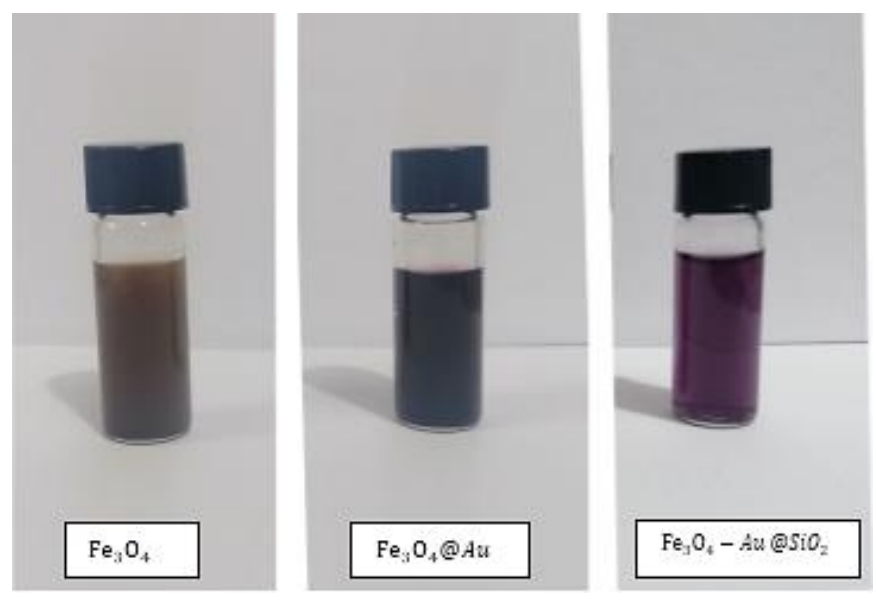

Figure 1: The solution of $\mathrm{Fe}_{3} \mathrm{O}_{4}-\mathrm{Au} @ \mathrm{SiO}_{2} \mathrm{CSNPs}$ 


\subsection{MTT assay}

The MTT assay was utilized to test the cytotoxic effect of $\mathrm{Fe}_{3} \mathrm{O}_{4}-\mathrm{Au} @ \mathrm{SiO}_{2} \mathrm{CSNPs}$. CAL51 and HBL-100 cell lines were cultured into 96-well plate $\left(1 \times 10^{4}\right.$ cells/well $)$ that contain a mixture of RPMI medium and fetal calf serum (10\%). The cells were cultured for $24 \mathrm{~h}$ to ensure cell adhesion to the wells. The cell lines were treated with different concentrations of $\mathrm{Fe}_{3} \mathrm{O}_{4}-\mathrm{Au} @ \mathrm{SiO}_{2}(3.1,6.25,12.5,25$ and $50 \mu \mathrm{g} / \mathrm{mL})$ in the absence and irradiated with NIR laser ( $808 \mathrm{~nm}$ laser, $0.5 \mathrm{~W} \cdot \mathrm{cm}^{-2}, 20 \mathrm{~min}$ ) and again when applying an alternating magnetic field ( $0.3 \mathrm{~T}$ for $25 \mathrm{~min})$. Untreated cell lines were cultured in a well plate to serve as the control. Cell viability was measured after $72 \mathrm{~h}$ of incubation. The media were discarded from the plate and washed three times with PBS. $28 \mu \mathrm{L}$ of 2 $\mathrm{mg} / \mathrm{mL}$ solution of MTT stain was added to each well and the plate was kept at $37^{\circ} \mathrm{C}$. After $2.5 \mathrm{~h}$, the MTT solution was removed with $130 \mu \mathrm{L}$ of DMSO (Dimethyl Sulphoxide). After this, the plates were incubated for $15 \mathrm{~min}$ at $37^{\circ} \mathrm{C}$ with shaking. The optical density of $\mathrm{Fe}_{3} \mathrm{O}_{4}-\mathrm{Au} @ \mathrm{SiO}_{2}$ and of the control for each well were read using a FLUO star OPTIMA device at $492 \mathrm{~nm}$. The cell growth inhibition rate and percentage of cytotoxicity of $\mathrm{Fe}_{3} \mathrm{O}_{4}-\mathrm{Au} @ \mathrm{SiO}_{2} \mathrm{CSNPs}$ were calculated according to Equation (1) [18].

Inhibition rate $=\frac{\mathrm{A}-\mathrm{B}}{\mathrm{A}} * 100$

where A represents the optical density of the control (cells only) and B represents the optical density of the samples.

Images of CAL-51 and HBL-100 cells, treated with $\mathrm{Fe}_{3} \mathrm{O}_{4}-\mathrm{Au} @ \mathrm{SiO}_{2}$ at a chosen concentration of $12.5 \mu \mathrm{g} / \mathrm{mL}$, were taken with a digital camera connected to an inverted microscope at $100 \times$ magnification.

\section{Characterisation}

LSPR of $\mathrm{Fe}_{3} \mathrm{O}_{4}-\mathrm{Au} @ \mathrm{SiO}_{2}$ was determined with a UV-Vis spectroscope (the Shimadzu UV-1601 spectrophotometer). X-ray diffractometer (XRD) (Shimadzu XRD 6000, Cu Ka radiation source) was utilized to analyze the structure of $\mathrm{Fe}_{3} \mathrm{O}_{4}-\mathrm{Au} @ \mathrm{SiO}_{2}$. Field Emission Scanning Electron Microscope (FESEM) (model: £IGMA Series-ZEISS Company) was used to analyze the NPs' size and morphological properties. Zetaplus device (from Brookhaven) was used to analyze the electric charge on the nanoparticles surface and the stability of the nanoparticles. The magnetization was measured at RT with a vibrating sample magnetometer (VSM, BVH-55). 


\section{Result and Discussion}

Fig.2 shows the XRD patterns of the synthesized $\mathrm{Fe}_{3} \mathrm{O}_{4} \mathrm{NPs}, \mathrm{Fe}_{3} \mathrm{O}_{4} @ \mathrm{Au} \mathrm{NPs}$ and $\mathrm{Fe}_{3} \mathrm{O}_{4}-\mathrm{Au} @ \mathrm{SiO}_{2} \mathrm{NPs}$. The $\mathrm{Fe}_{3} \mathrm{O}_{4}$ peaks are at $2 \theta=30.56^{\circ}, 35.86^{\circ}, 43.46^{\circ}, 54.01^{\circ}, 57.38^{\circ}$, $63.00^{\circ}$, and $74.46^{\circ}$, are assigned to (220), (311), (400), (422), (511), (440), and (533) respectively, matching the data of ICSD file no: 98-002-7899 [19]. $\mathrm{Fe}_{3} \mathrm{O}_{4} @ \mathrm{Au}$ nanoparticles have peaks identical to those of $\mathrm{Fe}_{3} \mathrm{O}_{4}$ nanoparticles but with additional peaks at $38.2^{\circ}, 44.3^{\circ}$, and $64.5^{\circ}$ ascribed to the fcc Au locations of (111), (200) and (220) planes respectively (ICSD file no: 98-005-2700) [20]. These results are consistent with those of Maximenko et al. [21]. The XRD pattern of the $\mathrm{Fe}_{3} \mathrm{O}_{4}-\mathrm{Au} @ \mathrm{SiO}_{2} \mathrm{CSNPs}$ is identical to the pattern of $\mathrm{Fe}_{3} \mathrm{O}_{4} @ \mathrm{Au}$ NPs, with the exception of the broad peak at $2 \theta=15-$ 25, which is due to the amorphous $\mathrm{SiO}_{2}$ [22]. This implies that the $\mathrm{SiO}_{2}$ shell around $\mathrm{Fe}_{3} \mathrm{O}_{4}$ $\mathrm{Au}$ has no effect on the initial stucture of $\mathrm{Fe}_{3} \mathrm{O}_{4}$-Au due to its good protective function. The average crystalline size of synthesized $\mathrm{Fe}_{3} \mathrm{O}_{4} \quad \mathrm{NPs}, \mathrm{Fe}_{3} \mathrm{O}_{4} @ \mathrm{Au} \quad \mathrm{NPs}$ and $\mathrm{Fe}_{3} \mathrm{O}_{4}-\mathrm{Au} @ \mathrm{SiO}_{2} \mathrm{NPs}$ can be estimated as 14,22 and $22.8 \mathrm{~nm}$ respectively. These were calculated using the Debye-Scherrer equation.

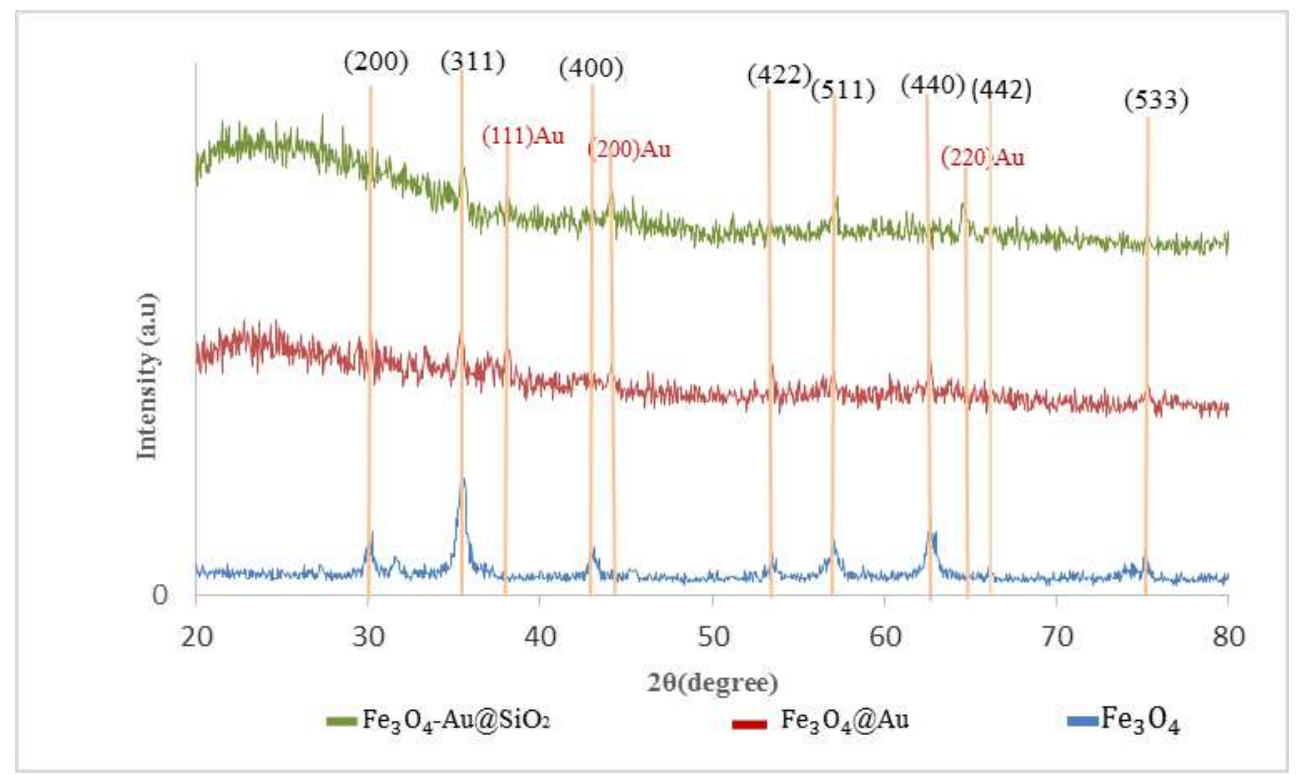

Figure 2: The XRD pattern of $\mathrm{Fe}_{3} \mathrm{O}_{4} \mathrm{NPs}, \mathrm{Fe}_{3} \mathrm{O}_{4} @ \mathrm{Au} \mathrm{NPs}$ and $\mathrm{Fe}_{3} \mathrm{O}_{4}-\mathrm{Au} @ \mathrm{SiO}_{2} \mathrm{CSNPs}$

The localized surface plasmon resonance (LSPR) can be determined using UV-Vis spectroscopy. The shape and position of the LSPR peak provides information on the scale, size, structure and stability of metal nanoparticles in aqueous solution [23]. Fig.3 shows the UV-Vis SPR spectra of $\mathrm{Fe}_{3} \mathrm{O}_{4} \mathrm{NPs}, \mathrm{Fe}_{3} \mathrm{O}_{4} @ \mathrm{Au} \mathrm{NPs}$ and $\mathrm{Fe}_{3} \mathrm{O}_{4}-\mathrm{Au} @ \mathrm{SiO}_{2} \mathrm{CSNPs}$. Magnetite NPs have plasmonic properties but they are not as powerful as gold NPs. This is because of the two materials' different electronic structures. The UV-Vis SPR spectrum of $\mathrm{Fe}_{3} \mathrm{O}_{4}$ is absent in the visible region. The LSPR of $\mathrm{Fe}_{3} \mathrm{O}_{4} @ \mathrm{Au}$ CSNPs normally appears at $530 \mathrm{~nm}$ but this peak shifted towards large wavelengths (red shift) due to $\mathrm{SiO}_{2}$ shell around $\mathrm{Fe}_{3} \mathrm{O}_{4} @ \mathrm{Au}$, The plasmon absorption shows up at $545 \mathrm{~nm}$. 

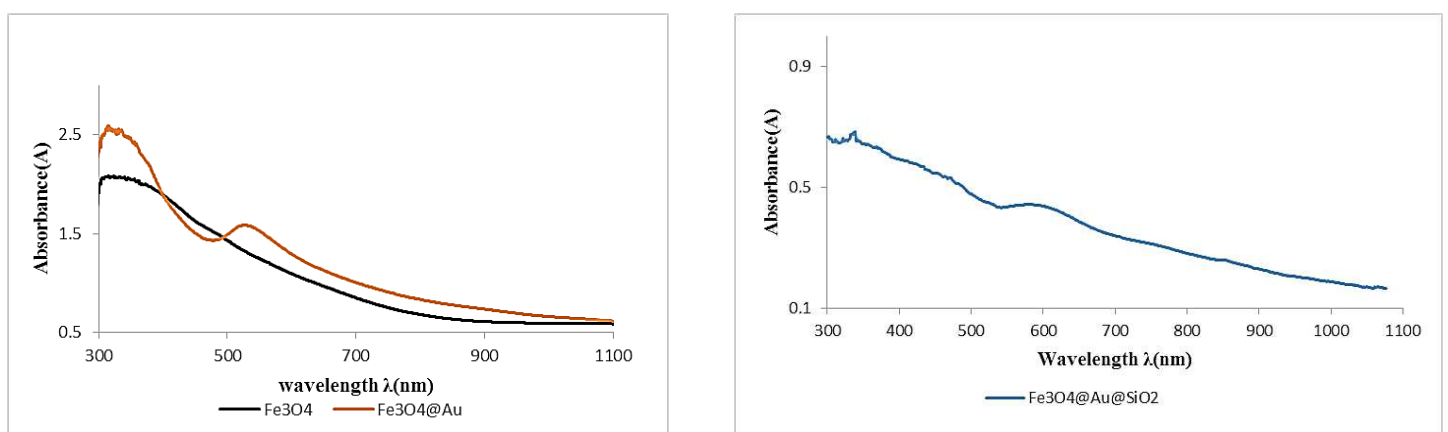

Figure 3: the UV-vis spectra of an aqueous solution of $\mathrm{Fe}_{3} \mathrm{O}_{4} \mathrm{NPs}, \mathrm{Fe}_{3} \mathrm{O}_{4} @ \mathrm{Au} \mathrm{NPs}$ and $\mathrm{Fe}_{3} \mathrm{O}_{4}$ - $\mathrm{Au} @ \mathrm{SiO}_{2} \mathrm{CSNPs}$

$\mathrm{Fe}_{3} \mathrm{O}_{4} \mathrm{NPs}, \mathrm{Fe}_{3} \mathrm{O}_{4} @ \mathrm{Au}$ CSNPs and $\mathrm{Fe}_{3} \mathrm{O}_{4}-\mathrm{Au} @ \mathrm{SiO}_{2}$ CSNPs were morphologically analysed using FESEM. Figs.4a-c depict the FESEM images of all the samples. Fig.4a shows $\mathrm{Fe}_{3} \mathrm{O}_{4} \mathrm{NPs}$ with many spherical particles and a particle size of about (10-2) nm. The image of the $\mathrm{Fe}_{3} \mathrm{O}_{4} @ \mathrm{Au}$ CSNPs sample is shown in Fig.4b and it appears that the particle size has increased with coating $\mathrm{Fe}_{3} \mathrm{O}_{4}$ by $\mathrm{Au}$, having an average particle size of $17.3 \mathrm{~nm}$. As illustrated in Fig.4c, $\mathrm{Fe}_{3} \mathrm{O}_{4}$-Au CSNPs coated with $\mathrm{SiO}_{2}$ shell appear darker, with particle sizes of about $22.5 \mathrm{~nm}$. Fig.4d is the TEM image of $\mathrm{Fe}_{3} \mathrm{O}_{4}-\mathrm{Au} @ \mathrm{SiO}_{2} \mathrm{CSNPs}$ that will be used for biomedical application. The image shows that it is spherical, with a particle size of $20 \mathrm{~nm}$.
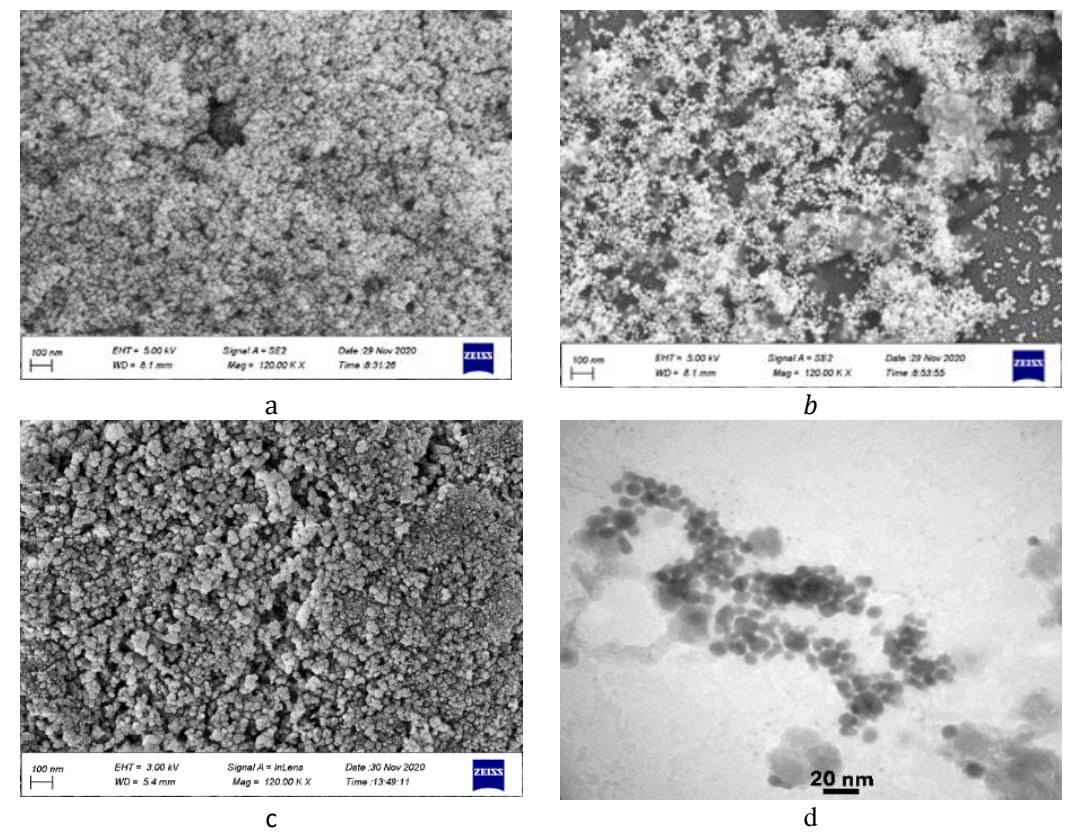

Figure 4 : FESEM images of a. $\mathrm{Fe}_{3} \mathrm{O}_{4} \mathrm{NPs}, \mathrm{b} . \mathrm{Fe}_{3} \mathrm{O}_{4} @ \mathrm{Au}$ CSNPs and c. $\mathrm{Fe}_{3} \mathrm{O}_{4}$-Au@ $@ \mathrm{SiO}_{2} \mathrm{CSNPs}$ d: TEM image of $\mathrm{Fe}_{3} \mathrm{O}_{4}-\mathrm{Au} @ \mathrm{SiO}_{2} \mathrm{CSNPs}$ 
When the $\mathrm{Fe}_{3} \mathrm{O}_{4}$ NPs are small enough (less than $30 \mathrm{~nm}$ ), they become superparamagnetic at room temperature [24]. The shell coated core causes increase in particle size that was proved by the XRD and the FESEM analyses. Particle size influences the magnetic characteristics of NPs. It is also reflected in the structure of the spin from the surface of the NPs. The magnetic properties of NPs increase as their size increases due to reduced surface effects. The decrease in surface area causes a decrease in surface disorder and an increase in inter-particle interactions, resulting in higher magnetic characteristics such as high saturation magnetization, agreeing with Silva et al. [25], while coating the NPs with the shell layer helps decrease the surface effect. The spins on the surface of the NP shells are no longer aligned, due to the action of the exchange or superexchange interaction (disorder structure) with the spins from the core of the nanoparticles that are aligned. The noncollinearity of the spins from the surface of the nanoparticles causes a decrease in saturation magnetization. Due to the mass contribution from the diamagnetic material $\left(\mathrm{SiO}_{2}-\mathrm{Au}\right)$ shell, CSNPs have much lower saturation magnetization (Ms) than $\mathrm{Fe}_{3} \mathrm{O}_{4} \mathrm{NPs}$, agreeing with Stafford et al. [26]. Fig.5 shows that the saturation magnetization Ms and remanent magnetization $\mathrm{Mr}$ decrease while coercive force increases by coating the NPs with $\mathrm{Au}$ and $\mathrm{SiO}_{2}$. The increase of coercivity may be related to the impact of the spin disorder at the $\mathrm{Fe}_{3} \mathrm{O}_{4}$-Au interface and to the weak interchange of surface and core spins, (shown in Table 1).

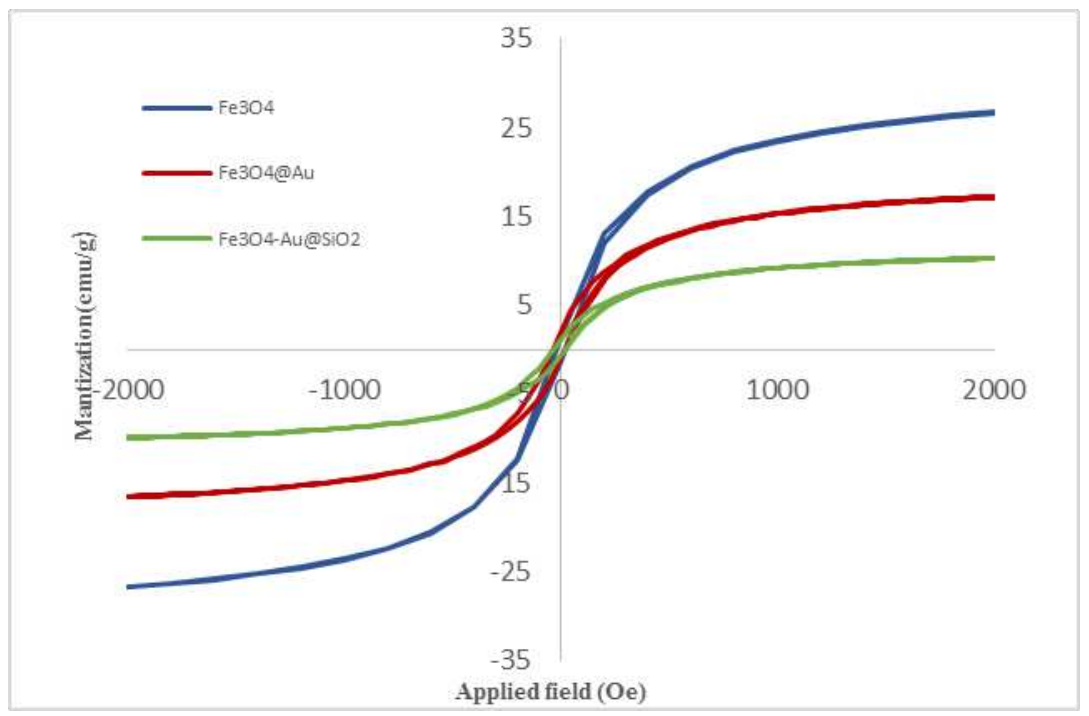

Figure 5: Hysteresis loops of $\mathrm{Fe}_{3} \mathrm{O}_{4} \mathrm{NPs}, \mathrm{Fe}_{3} \mathrm{O}_{4} @ \mathrm{Au} \mathrm{NPs}$ and $\mathrm{Fe}_{3} \mathrm{O}_{4}-\mathrm{Au} @ \mathrm{SiO}_{2}$ nanoparticles synthesized at RT

Table 1. Magnetic parameters

\begin{tabular}{|l|c|c|c|c|}
\hline $\mathrm{S}$ & $\begin{array}{c}\text { saturation magnetization } \\
{[\mathrm{Ms}] \mathrm{emu} / \mathrm{g}}\end{array}$ & $\begin{array}{c}\text { the remanent magnetization } \\
{[\mathrm{Mr}] \mathrm{emu} / \mathrm{g}}\end{array}$ & $\begin{array}{c}\text { the coercivity [Hc] } \\
\text { Oe }\end{array}$ & Particle size from FESEM [nm] \\
\hline $\mathrm{Fe}_{3} \mathrm{O}_{4}$ & 26.6 & 1.4 & 8 & 9 \\
\hline $\mathrm{Fe}_{3} \mathrm{O}_{4} @ \mathrm{Au}$ & 17 & 1.8 & 15 & 17.3 \\
\hline $\mathrm{Fe}_{3} \mathrm{O}_{4}-\mathrm{Au} @ \mathrm{SiO}_{2}$ & 10 & 1.1 & 21 & 22.5 \\
\hline
\end{tabular}


Measurement of zeta potential gives information on surface function, particle stability and the interaction of dissolved compounds with the surface. The zeta potential magnitude reflects sample stability whereas the zeta potential sign shows whether the surface is dominated by positive or negative charges [27]. The zeta potential was utilized to analyze the stability of the prepared $\mathrm{Fe}_{3} \mathrm{O}_{4}-\mathrm{Au} @ \mathrm{SiO}_{2}$ NPs. The $\mathrm{Fe}_{3} \mathrm{O}_{4}-\mathrm{Au} @ \mathrm{SiO}_{2}$ CSNPs had a stable dispersion of about $-49.1 \mathrm{mV}$, as shown in Fig.6. The nanoparticles that have zeta potential values higher than $\pm 30 \mathrm{mV}$ are used in medical applications due to good dispersity and high suspension stability.

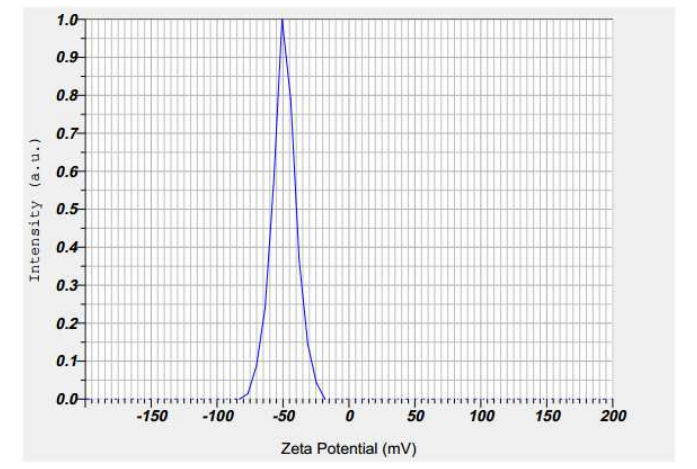

Figure 6: zeta potential measurement of $\mathrm{Fe}_{3} \mathrm{O}_{4}-\mathrm{Au} @ \mathrm{SiO}_{2}$

Use of the MTT assay to study the cytotoxic effect of $\mathrm{Fe}_{3} \mathrm{O}_{4}-\mathrm{Au} @ \mathrm{SiO}_{2} \mathrm{CSNPs}$ dispersed in deionized water at different concentrations $(3.125,6.25,12.5,25$ and $50 \mu \mathrm{g} / \mathrm{mL})$ is shown in Fig.7. Exposure of cell lines to $\mathrm{Fe}_{3} \mathrm{O}_{4}-\mathrm{Au} @ \mathrm{SiO}_{2} \mathrm{CSNPs}$ caused a reduction in the viability of cancer cells. The cytotoxic effects of these cell lines increased with the increase of $\mathrm{Fe}_{3} \mathrm{O}_{4}-\mathrm{Au} @ \mathrm{SiO}_{2} \mathrm{CSNP}$ concentration. The results show that $\mathrm{Fe}_{3} \mathrm{O}_{4}-\mathrm{Au} @ \mathrm{SiO}_{2}$ CSNPs have the ability to inhibit the proliferation of cancer cells and cell death when comparing cell lines with tumours (CAL-51) and normal cell lines (HBL-100), as the tumour cell death in CAL-51 was approximately $70 \%$, contrasting with approximately $13 \%$ in HBL-100 at the highest $\mathrm{Fe}_{3} \mathrm{O}_{4}-\mathrm{Au} @ \mathrm{SiO}_{2}$ concentration (the black bars in Fig.7). To achieve more cell death, the cell lines with the NPs were irradiated for 20 min with NIR of $808 \mathrm{~nm}$ wavelength and at $0.5 \mathrm{~W} \mathrm{~cm}$. The irradiation light is absorbed by LSPR (Au NPs) and converted to heat and forms a hot metallic lattice by electron-electron relaxation and electron-phonon relaxation. Heat energy is precipitated in the tumour cell lines, causing them to inhibit the proliferation of cancer cells and therefore their death (the red bars of Fig.7). Photothermal effect of $\mathrm{Fe}_{3} \mathrm{O}_{4}-\mathrm{Au} @ \mathrm{SiO}_{2}$ results in a significant reduction of the tumour, since cell lines are sensitive to heat. Higher tumour cell killing was noticed with the use of NIR radiation. Tumour cell killing was approximately $75 \%$ for CAL-51 and about $15 \%$ for the HBL-100, at the highest $\mathrm{Fe}_{3} \mathrm{O}_{4}-\mathrm{Au} @ \mathrm{SiO}_{2}$ concentration. The cytotoxic effect was increased under laser irradiation due to increased absorption, induced by the distinct properties of LSPR. Furthermore, because of the smaller particle size, the larger light energy from the NIR laser was converted to heat energy, agreeing with Huang et al. [28]. Applying an alternating magnetic field (AMF) ( $0.3 \mathrm{~T})$ for 25 min caused even 
more cancer cell death (higher cytotoxity) (the green bars in Fig.7). Applying an alternating magnetic field (AMF) ( $0.3 \mathrm{~T}$ ) for 25 min caused even more cancer cell death (higher cytotoxity) (the green bars in Fig.7). AMF causes the $\mathrm{Fe}_{3} \mathrm{O}_{4}$ in cancer cells to spin back and forth, thus generating a significant amount of heat and causing the death of the tumour cells. The highest tumour cell death was about $85 \%$ for CAL-51 and about $16 \%$ for HBL-100 at the highest $\mathrm{Fe}_{3} \mathrm{O}_{4}-\mathrm{Au} @ \mathrm{SiO}_{2}$ concentration. The magnetite centre could still spin and create heat in a magnetic field. Current findings indicate that the photothermal effect of $\mathrm{Fe}_{3} \mathrm{O}_{4}-\mathrm{Au} @ \mathrm{SiO}_{2}$ with the application of AMF achieves the highest rate of tumour cell death. Both NIR radiation and AMF cause greater death in tumour cells containing $\mathrm{Fe}_{3} \mathrm{O}_{4}-\mathrm{Au} @ \mathrm{SiO}_{2} \mathrm{CSNPs}$, as these resulted in a rapid increase in temperature inside the cell lines.

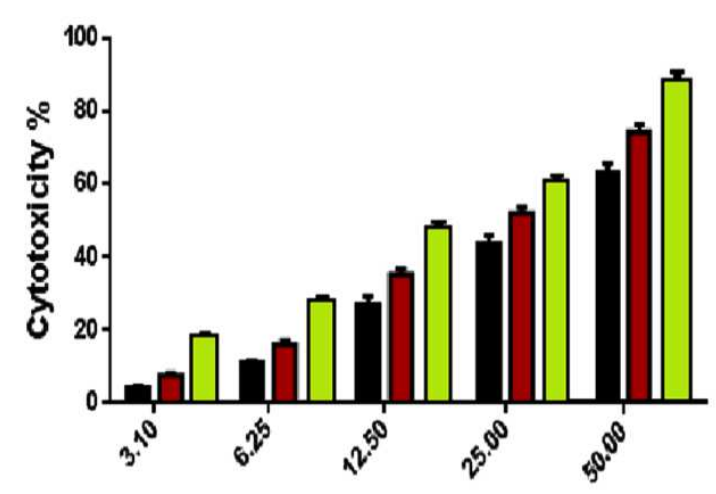

CAL-51 cells

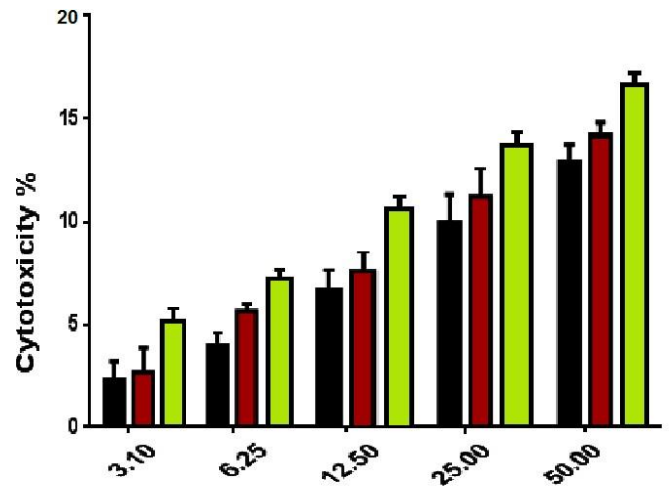

HBL-100 cells

Figure 7: Cytotoxic effect on two cell lines with $\mathrm{Fe}_{3} \mathrm{O}_{4}-\mathrm{Au} @ \mathrm{SiO}_{2}($

+NIR , $\square+\mathrm{AMF})$

Treating CAL-51 and HBL-100 cell lines with $\mathrm{Fe}_{3} \mathrm{O}_{4}-\mathrm{Au} @ \mathrm{SiO}_{2} \mathrm{CSNPs}$, in the presence of laser and AMF produced cellular damage. This is most likely because of the photothermal effect. Changes in morphology and cell viability, as compared with the control, were noticed from the microscope images as presented in Fig.8. 


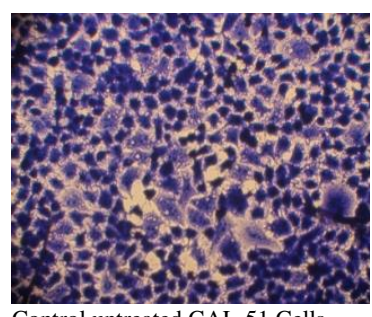

Control untreated CAL-51 Cells

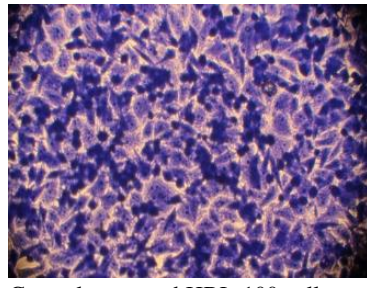

Control untreated HBL-100 cells

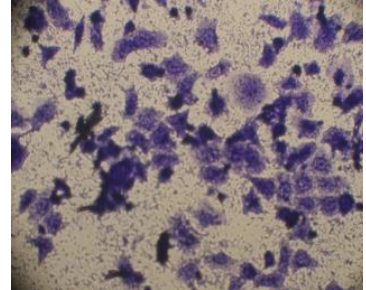

CAL-51 cells after treated

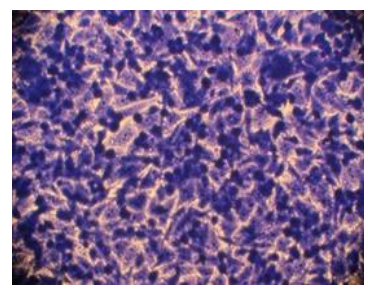

HBL-100 cells after treated
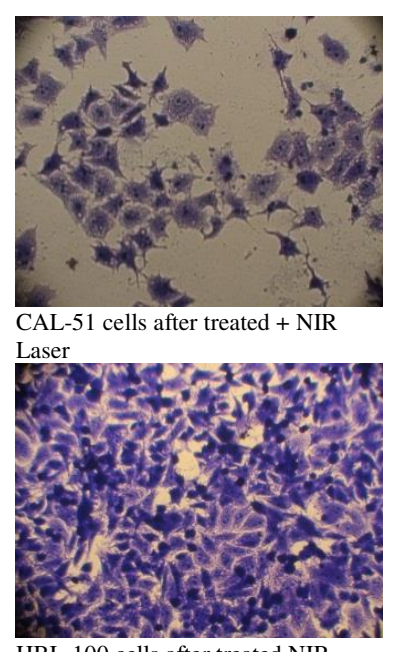

HBL-100 cells after treated NIR Laser

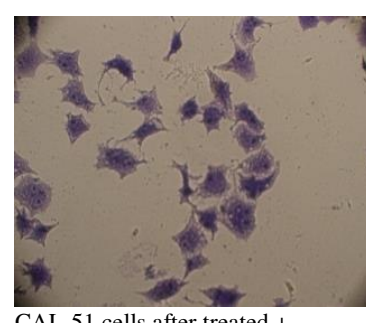

CAL-51 cells after treated + AMF

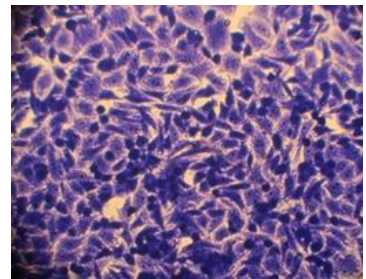

HBL-100 cells after treated AMF

Figure 8:Microscopy image of cell lines CAL-51, and HBL-100 after treatment with $\mathrm{Fe}_{3} \mathrm{O}_{4}-\mathrm{Au} @ \mathrm{SiO}_{2}+(\mathrm{NIR}, \mathrm{AMF})$ morphology

\section{Conclusions}

In this study, $\mathrm{Fe}_{3} \mathrm{O}_{4}-\mathrm{Au} @ \mathrm{SiO}_{2}$ was synthesized in a short time, with desired physicochemical characteristics and effective biocompatibility. In UV-Vis spectroscopy, the shift in LSPR peak to a longer wavelength (red shift) confirmed that the core-shell had formed. A LSPR peak of $\mathrm{Fe}_{3} \mathrm{O}_{4} @ \mathrm{Au}$ appears at $530 \mathrm{~nm}$ and shifts to $545 \mathrm{~nm}$ when coated with $\mathrm{SiO}_{2}$. The particle size was obtained from the FESEM image and XRD analysis, showing the increase in size of particles with a shell. In addition, the TEM images show a spherical shape, with a particle size of $20 \mathrm{~nm}$, with a clear appearance of $\mathrm{Fe}_{3} \mathrm{O}_{4}-\mathrm{Au} @ \mathrm{SiO}_{2}$ CSNPs. VSM indicated that the magnetization was decreased due to being coated by $\mathrm{Au}$ and $\mathrm{SiO}_{2}$. Exposure of cell lines to $\mathrm{Fe}_{3} \mathrm{O}_{4}-\mathrm{Au} @ \mathrm{SiO}_{2} \mathrm{CSNPs}$ caused a reduction in the viability of cancer cells. The application of NIR radiation caused greater cell death, at around $70 \%$ for CAL-51 and about $20 \%$ for HBL-100. The application of alternating magnetic field also caused increased cell death, at around $80 \%$ for CAL-51 and about $30 \%$ for HBL-100.

\section{References}

[1] Goswami MM, Dey C, Bandyopadhyay A, Sarkar D, Ahir M. Micelles driven magnetite (Fe3O4) hollow spheres and a study on AC magnetic properties for hyperthermia application. J. Magn. Magn. Mater. (2016) Nov 1;417:376-81. https://doi.org/10.1016/j.jmmm.2016.05.069

[2] Xia KK, Lyu Y, Yuan WT, Wang GX, Stratton H, Zhang SJ, Wu J. Nanocarriers of Fe3O4 as a novel method for delivery of the antineoplastic agent doxorubicin into HeLa cells in vitro. Front. Oncol. (2019) Apr 10;9:250. https://doi.org/10.3389/fonc.2019.00250 
[3] Kappiyoor R, Liangruksa M, Ganguly R, Puri IK. The effects of magnetic nanoparticle properties on magnetic fluid hyperthermia. J. Appl. Phys. (2010) Nov 1;108(9):094702. https://doi.org/10.1063/1.3500337

[4] Yew YP, Shameli K, Mohamad SE, Lee KX, Teow SY. Green synthesized montmorillonite /carrageenan /Fe3O4 nanocomposites for $\mathrm{pH}$-responsive release of protocatechuic acid and its anticancer activity. Int. J. Mol. Sci. (2020) Jan;21(14):4851. https://doi.org/10.3390/ijms21144851

[5] Fortin JP, Gazeau F, Wilhelm C. Intracellular heating of living cells through Néel relaxation of magnetic nanoparticles. Eur. Biophys. J. (2008) Feb;37(2):223-8. https://doi.org/10.1007/s00249-007-0197-4

[6] Liao Z, Wang H, Lv R, Zhao P, Sun X, Wang S, Su W, Niu R, Chang J. Polymeric liposomes-coated superparamagnetic iron oxide nanoparticles as contrast agent for targeted magnetic resonance imaging of cancer cells. Langmuir. (2011) Mar 15;27(6):3100-5. https://doi.org/10.1021/la1050157

[7] Abdallah RM, Al-Haddad RM. Optical and Morphology Properties of the Magnetite (Fe3O4) Nanoparticles Prepared by Green Method. J Phys Conf Ser. (2021)Mar 1;1829(1); 012022. IOP Publishing. https://iopscience.iop.org/article/10.1088/1742-6596/1829/1/012022

[8] Armelles G, Cebollada A, García-Martín A, González MU. Magnetoplasmonics: combining magnetic and plasmonic functionalities. Adv. Opt. Mater. (2013) Jan;1(1):10-35. https://doi.org/10.1002/adom.201200011

[9] Dykman L, Khlebtsov N. Gold nanoparticles in biomedical applications: recent advances and perspectives. Chem. Soc. Rev.. 2012;41(6):2256-82. https://doi.org/10.1039/C1CS15166E

[10] Kelly KL, Coronado E, Zhao LL, Schatz GC. The optical properties of metal nanoparticles: the influence of size, shape, and dielectricenvironment. J. Phys. Chem. B .(2003);107:668-77. https://doi.org/10.1021/jp026731y

[11] Jain PK, Lee KS, El-Sayed IH, El-Sayed MA. Calculated absorption and scattering properties of gold nanoparticles of different size, shape, and composition: applications in biological imaging and biomedicine. J. Phys. Chem. B.(2006) Apr 13;110(14):7238-48. https://doi.org/10.1021/jp057170o

[12] Abbas M, Rao BP, Islam MN, Naga SM, Takahashi M, Kim C. Highly stable-silica encapsulating magnetite nanoparticles $(\mathrm{Fe} 3 \mathrm{O} 4 / \mathrm{SiO} 2)$ synthesized using single surfactantless-polyol process. Ceram. Int. (2014) Jan 1;40(1):1379-85. https://doi.org/10.1016/j.ceramint.2013.07.019

[13] Hou X, Wang X, Liu R, Zhang H, Liu X, Zhang Y. Facile synthesis of multifunctional Fe3O4@SiO2@Au magneto-plasmonic nanoparticles for MR/CT dual imaging and photothermal therapy. RSC Adv. (2017);7(31):18844-50. https://doi.org/10.1039/C7RA00925A

[14] Ibarra MR, Khlebtsov NG. Magnetic and Plasmonic Nanoparticles for Biomedical Devices. Appl. Sci. (2019);126, 170401. https://doi.org/10.1063/1.5130560

[15] Yang K, Dai Z, Chu Y, Chen G. Preparation of yolk-shell microspheres as temperature switch on/off catalysts. Micro \& Nano Letters. 2016 Mar 31;11(3):129-36. https://doi.org/10.1049/mnl.2015.0435

[16] Amatatongchai M, Sitanurak J, Sroysee W, Sodanat S, Chairam S, Jarujamrus P, Nacapricha D, Lieberzeit PA. Highly sensitive and selective electrochemical paper-based device using a graphite screenprinted electrode modified with molecularly imprinted polymers coated Fe3O4@Au@SiO2 for serotonin determination. Analytica chimica acta. 2019 Oct 24;1077:255-65. https://doi.org/10.1016/j.aca.2019.05.047

[17] Dheyab MA, Aziz AA, Khaniabadi PM, Jameel MS. Potential of a sonochemical approach to generate MRI-PPT theranostic agents for breast cancer. Photodiagnosis Photodyn Ther.(2021) Mar 1;33:102177. https://doi.org/10.1016/j.pdpdt.2021.102177 
[18] Jabir MS, Hussien AA, Sulaiman GM, Yaseen NY, Dewir YH, Alwahibi MS, Soliman DA, Rizwana H. Green synthesis of silver nanoparticles from Eriobotrya japonica extract: a promising approach against cancer cells proliferation, inflammation, allergic disorders and phagocytosis induction. Artif Cells Nanomed Biotechnol.(2021) Jan 1;49(1):48-60. https://doi.org/10.1080/21691401.2020.1867152

[19] Abdulghani AJ, Al-Ogedy WM. Synthesis and Characterization of Multishapes of Fe3O4 Nanoparticle by Solve-Hydrothermal Method Using Microwave Radiation. Baghdad Sci. J. (2016);13(2). https://doi.org/10.21123/bsj.2016.13.2.0331

[20] Hussein EA, Zagho MM, Rizeq BR, Younes NN, Pintus G, Mahmoud KA, Nasrallah GK, Elzatahry AA. Plasmonic MXene-based nanocomposites exhibiting photothermal therapeutic effects with lower acute toxicity than pure MXene. Int. J. Nanomedicine.(2019);14:4529. https://doi.org/10.2147/IJN.S202208

[21] Maximenko A, Depciuch J, Łopuszyńska N, Stec M, Światkowska-Warkocka Ż, Bayev V, Zieliński PM, Baran J, Fedotova J, Węglarz WP, Parlinska-Wojtan M. Fe 3 O 4@SiO 2@ Au nanoparticles for MRIguided chemo/NIR photothermal therapy of cancer cells. RSC Adv.(2020);10(44):26508-20. https://doi.org/10.1039/D0RA03699D

[22] Yetim NK, Baysak FK, Koç MM, Nartop D. Characterization of magnetic Fe3O4@ SiO2 nanoparticles with fluorescent properties for potential multipurpose imaging and theranostic applications. J. Mater. Sci. Mater. Electron.(2020)Oct;31(20):18278-88. https://doi.org/10.1007/s10854-020-04375-7

[23] Kwizera EA, Chaffin E, Wang Y, Huang X. Synthesis and properties of magnetic-optical core-shell nanoparticles. RSC Adv.(2017);7(28):17137-53. https://doi.org/10.1039/C7RA01224A

[24] Caizer C. Nanoparticle size effect on some magnetic properties. Handbook of Nanoparticles.(2016):475. Springer, Cham. https://doi.org/10.1007/978-3-319-13188-7_24-1

[25] Silva RL, Figueiredo AT, Barrado CM, Sousa MH. Luminescent and magnetic properties of Fe3O4@ SiO2: phen: Eu3+. J. Mater. Res.(2017)Oct;20(5):1317-21. https://doi.org/10.1590/1980-5373-MR-2016$\underline{0838}$

[26] Stafford S, Serrano Garcia R, Gun'ko YK. Multimodal magnetic-plasmonic nanoparticles for biomedical applications. Appl. Sci.(2018);8(1):97. https://doi.org/10.3390/app8010097

[27] Contreras MF, Sougrat R, Zaher A, Ravasi T, Kosel J. Non-chemotoxic induction of cancer cell death using magnetic nanowires. Int. J. Nanomedicine. (2015);10:2141. https://doi.org/10.2147/IJN.S77081

[28] Huang HS, Hainfeld JF. Intravenous magnetic nanoparticle cancer hyperthermia. Int. J. Nanomedicine. (2013);8:2521. https://doi.org/10.2147/IJN.S43770 